\title{
ANEXO:
}

\section{PRESSUPOSTOS TEÓRICO-BIOLÓGICOS PARA UMA ANÁLISE JURÍDICA DOS ORGANISMOS GENETICAMENTE MODIFICADOS}

\author{
Gustavo Ferraz de Campos Mônaco \\ Doutorando em Direito Internacional pela Faculdade de \\ Direito da Universidade de São Paulo.
}

SUMÁRIO: 1. Da engenharia genética: a evolução científica que desemboca nos organismos geneticamente modificados - 2. Da ecologia: o ecossistema e sua interação com os organismos geneticamente modificados

1. Da engenharia genética: a evolução científica que desemboca nos organismos geneticamente modificados.

A transmissão das características genéticas entre os seres vivos, de geração para geração, teve o início de seu conhecimento desvendado pelo homem graças às pesquisas de Mendel ${ }^{1}$ que observou o cruzamento de algumas gerações de ervilhas e de seus resultados, se extraiu regras matemáticas relacionadas à probabilidade de transmissão das características genéticas entre as sucessivas gerações.

A comunidade científica percebeu, por meio destes estudos, que algumas características genéticas não se manifestavam em razão de haver uma outra característica a ela assemelhada e que acabava por encobrir aquela outra. Chegou-se à conclusão da existência de genes dominantes, ao lado de genes recessivos. Estes últimos, apesar de não se manifestarem no transcurso da vida de seu portador, podiam ser transmitidos à sua descendência, segundo as referidas regras de probabilidade.

I. GUIDO FERnANDo SIlVA SOARES faz menção, todavia, ao conhecimento empirico do homem, desde tempos imemoriais, que contribui para a seleção das espécies na medida em que cram escolhidos os melhores espécimes vegetais para a extração de suas sementes para o replantio, bem como que, dos melhores animais para os cruzamentos com lins reprodutivos (Organismos geneticamente modificados (OGM), a legislação brasileira e os principios e normas do direito internacional do meio ambiente parecer. Biotecnologia no Brasil - uma abordagem juridica, p. 38-39). Esta técnica é chamada de seleção que pode ser intra e interpopulacional. Cf ERNESTO PATERNIANI. Uma percepção crítica sobre técnicas de manipulação genética. Revista Brasileira de Milho e Sorgo, v. I, n. 1, p. 77-84, 2002. 
A probabilidade referida decorre do fenômeno celular denominado meiose, responsável pela formação das células gurminativas, ou gametas, que contém parte das informações genéticas do individuo que a originou. Isso se deve ao fato de cada célula germinativa possuir metade do material genético normalmente encontrado em uma célula estrutural, ou seja, daquelas células que formam os tecidos, órgãos e sistemas de um corpo vivo. O fenômeno da meiose é extremamente complexo e diferenciado, e só ocorre em algumas células preparadas para esta função reprodutora.

O que ocorre é que a divisão de uma célula desta natureza dá origem a quatro células diferentes e que contém, cada uma, material genético diversificado, mas que poderá (sempre) ser reconduzido à célula original, vale dizer, à célula que sofreu a divisão meiótica.

O fenômeno da meiose e a conseqüente delegação de material genético diversificado aos futuros descendentes, segundo regras de probabilidade, só pôde ser inteiramente explicado. no entanto, com a descoberta da estrutura das moléculas de DNA (ácido desoxirribonucléico).

Estas moléculas, formadas pelo encadeamento de bases nitrogenadas assumem a feição helicoidal, assemelhando-se a um par de escadas retorcidas, como que em forma de dois caracóis. e que não chegam a se tocar, mantendo sempre a mesma distância e o mesmo equilibrio. Este equilibrio se deve ao fato de as quatro bases nitrogenadas que entram na composição da molécula espelharem-se mutuamente sempre numa mesma e constante proporção (adenina com timina e guanina com citosina). Quer isto significar que a base nitrogenada de um tipo fará sempre par com uma certa e determinada base nitrogenada de outro tipo (por exemplo, a adenina e a timina), o mesmo ocorrendo com as outras duas bases nitrogenadas (na hipótese, a guanina e a citosina).

Quando ocorre o fenômeno da divisão celular. estas moléculas de DNA criam réplicas de si mesmas de forma a que as bases nitrogenadas do topo da escada afastem-se mutuamente e unam-se a outras bases nitrogenadas que passam a espelhálas (assim, se aquele primeiro par se afasta, outras duas moléculas unem-se a elas, uma de timina com a adenina e outra de adenina com a timina pré-existente). Este fenômeno ocorre $\mathrm{cm}$ um crescendo até que toda a estrutura tenha sido finalmente duplicada e até que as duas novas moléculas, idênticas, afastem-se de forma a dar origem a duas novas células, com a mesma composição da célula anterior. Este é o fenômeno da mitose, responsável pela reprodução e renovação das células que compõ cm um corpo vivo. 
Todavia, na meiose, após a verificação deste fenômeno, outro ainda é verificado, no qual cada uma das células originadas sofre nova divisão de suas moléculas de DNA que deixam de apresentar a forma helicoidal e passam a ser formadas por um único filamento. Em uma linguagem figurada, poder-se-ia comparar esta última divisão com a abertura de um ziper, ocasionando a separação definitiva de cada uma das "escadas em caracol"

Tal separação definitiva, que ocorre em ambas as células por primeiro duplicadas dá origem a duas novas células, o que permite afirmar que ao final do processo de divisão meiótica, estar-se-á na presença de quatro células de diferente conteúdo. A diferença de conteúdo se explica pela possibilidade que as moléculas de DNA têm, durante o processo de meiose, de ocasionar a intersecção de partes mais ou menos longas e/ou numerosas de seus filamentos, garantindo assim a diversidade de caracteristicas entre os seres de uma mesma espécie. Assim, o pai que possua um gene dominante para a característica cor de olho e outro gene recessivo para esta mesma característica dará origem, após a meiose, a quatro células que carregarão duas delas o gene recessivo e as outras duas o gene dominante. Se somarmos a isto uma outra característica como a do tipo sanguíneo, em que o mesmo pai possui um gene para sangue tipo $\mathrm{A}$ e outro para sangue tipo $\mathrm{B}$, teremos quatro diferentes células germinativas, a saber: (i) cor de olho recessivo e sangue tipo A; (ii) cor de olho recessivo e sangue tipo $\mathrm{B}$; (iii) cor de olho dominante e sangue tipo $\mathrm{A}$ e (iv) cor de olho dominante e sangue tipo B.

Percebe-se que a diversidade de células reprodutoras será tanto maior quanto maior forem as características analisadas e a diversidade de possibilidade de manifestação para uma mesma característica (por exemplo, sangue tipo A, B. O ou AB; tipo M, N, MN; tipo Rh positivo ou negativo). Daí a importância da diversidade biológica. $^{2}$

Outro fenômeno relativo ao DNA, porque nele encontra a sua origem, é aquele relativo à síntese protéica. Com efeito, toda proteína produzida por um

2. ElIANA MARIA GOUVEIA FonTES informa que um estudo publicado na revista Nature, em 1997. indica que certos cientistas procederam à estimativa dos custos de certos serviços realizados pela biodiversidade: "chegando ao valor de uma média de 33 trilhões de dólares anuais [caso viessem de ser realizados pelos homens]. Comparado ao Produto Internacional Bruto, que é de 18 trilhôes de dólares, podemos ter uma estimativa do valor dos serviços prestados pela diversidade biológica e o quanto é importante para a manutenção do sistema da vida no planeta". (Questões sobre biossegurança: Seminário Internacional sobre Direito da Biodiversidade. Revista (EJ, Brasilia, v. 3, n. 8, p. 127, maio'ago. 1999). Ver, ainda, MARCELo LeITE. Os genes da discórdia: alimentos transgênicos no Brasil. Parcerias Estratégicas, Brasilia, n. 10, p. 174-85, mar. 2001. 
organismo é sintetizada com o auxílio de ribossomos, estruturas celulares formadas por RNA (ácido ribonucléico) do tipo r (RNA ribossômico) que tem sua origem mediata no DNA e que são capazes de decodificar o código genútico de um indivíduo para sintetizar proteinas a partir da leitura do RNA do tipo m (RNA mensageiro).

O RNAr é capaz de ler a estrutura do RNAm verificando seqüências trinas de bases nitrogenadas. Para cada uma dessas seqüências trinas, o RNAr é capaz de aprisionar um aminoácido diferente (e equivalente àquela seqüência trina). Por seu tumo. um outro RNAr compatível com a seqüência trina posterior terá procedido à leitura da seqüência subseqüente e, enxergando nela um outro aminoácido, determinará a sua ligação ao primeiro. Este mecanismo é seguido até o final do RNAm e dá origem a uma proteína qualquer, vital para a manutenção do organismo.

A importância do DNA está justamente no fato de que o RNAm tenha a sua origem imediata em uma de suas seqüencias de bases nitrogenadas, por meio de processos químicos semelhantes ao da divisão celular, posto que o RNA, formado por uma cadeia simples (e não dupla) de bases nitrogenadas, será formado segundo o mesmo procedimento de se espelhar na estrutura do DNA, servindo-se de uma base determinada como reflexo para aquela base presente na estrutura do DNA. Neste sentido, então, é o DNA que contém as informações para a síntese protéica.

É certo que cada proteína desenvolve uma função especifica e determinada no funcionamento e na estruturação de um dado organismo, sem a qual, este último poderá ter o seu funcionamento dificultado, a sua estrutura prejudicada, podendo-se, inclusive, levar o indivíduo a óbito.

Todavia, nem todos os seres vivos possuem a capacidade para sintetizar todas as proteinas necessárias para a manutenção de suas atividades vitais. Neste sentido, aquela pessoa que sofre de diabetes, por exemplo. apresenta déficit ou mesmo a impossibilidade de sintetizar a proteína chamada insulina, responsável pela absorção dos açúcares pelo organismo.

Assim. as pesquisas genéticas levaram o homem ao conhecimento de técnicas que permitiram unir ao DNA de uma bactéria, de forma artificial, um trecho de DNA que fosse responsável pela síntese da insulina humana. Isto só foi possível em razão da descoberta de outra técnica de engenharia genútica denominada DNA 
recombinante, ${ }^{3}$ segundo a qual um trecho de DNA de uma espécie é enxertado no DNA de uma outra espécie que adquire a capacidade de sintetizar aquela proteína anteriormente inexistente em sua espécie. Antes da descoberta da técnica do DNA recombinante era impossivel seccionar uma molécula de DNA, pois não se sabia como proceder para_oliplói-la.

Por esta técnica, os RNAr do organismo geneticamente modificado pela inclusão de um trecho de DNA são “enganados" pelo homem e passam a produzir uma proteína até então impossivel de ser produzida por aquela espécie, posto que não houvesse, até então, a "ordem" para a sua síntese por parte do RNAm. Todavia, com a inclusão daquele trecho de DNA recombinante, o RNAm passa a ser diferente do original e, em conseqüência, passa a determinar a síntese da proteína.

Foi assim que a insulina pôde ser disponibilizada aos diabéticos, posto que não era possivel, como ainda não é, enxertar este trecho de DNA no próprio patrimônio genético do homem que sofresse de diabetes, reconstituindo a sua própria atividade. Com efeito, uma das características primordiais da técnica do DNA recombinante é a de não poder ser utilizado em células somáticas (estruturais), mas tão-só, em células germinativas.

A utilização da técnica do DNA recombinante, então, passou a ser largamente utilizada e passou a garantir algo que até então era inimaginável: transferir características atinentes a uma espécie para uma outra espécie, seja ela do mesmo ou de diferente reino. Assim, trechos de DNA animal podem ser combinados com trechos de DNA vegetal para que o vegetal modificado geneticamente passe a emanar características daquele DNA animal.

Até a descoberta da técnica do DNA recombinante a possibilidade de transferência de características genéticas de uma espécie para a outra só era possível por meio da reprodução sexuada que, no entanto, gerava um tertium genus, uma terceira espécie, normalmente estéril, como é o caso da mula e do burro, cruzamento de cavalos e asnos.

Outro aspecto relevante era o de que nem todas as espécies diferentes eram passiveis de cruzamento fora de sua espécie. Para que estes cruzamentos entre membros de espécies diferentes fossem possíveis era necessário haver entre eles

3. Na verdade, esta técnica é a base imediata de toda a atividade de engenharia genética. Para uma verificação do papel das enzimas endonucleases e das ligases neste processo, consulte-se Jost: PETERS, Experiências no Brasil: prós e contras da liberação de transgênicos no ambiente. Biossegurança: uma visão interdisciplinar, p. 41 e seguintes. 
compatibilidade sexual, ou seja, era preciso que o coito não fosse obstado por características como o tamanho dos animais, a posição de seus órgãos sexuais etc. e era preciso, ainda, que houvesse compatibilidade zigótica, ou seja, era preciso que não-obstante a realização do ato sexual fosse possível a união dos gametas de ambas as espécies, formando um zigoto. Esta última forma de compatibilidade depende - e muito, mas não apenas - da quantidade de cromossomos em cada um dos gametas. Assim, um cruzamento entre uma mulher e um cão … presente eventualmente a compatibilidade para o coito - certamente não daria resultado, uma vez que faltaria entre eles compatibilidade zigótica.

Desta forma, um homem nunca poderia adquirir uma característica genética canina, nem um cão poderia adquirir uma característica genética humana. Todavia, com a técnica do DNA recombinante, isto já se torna possivel pela simples inclusão de um trecho de DNA humano no patrimônio genético do cão ou vice-versa, sem que para isso seja necessária a produção de um híbrido do ponto de vista fenotípico. ${ }^{4}$

A utilização da técnica do DNA recombinante, então, possibilita que características de uma espécie se manifestem em uma outra espécie diferente. Vale dizer, aquilo que era atributo exclusivo de uma espécie pode passar a ser atributo de uma outra espécie.

2. Da ecologia: o ecossistema e sua interação com os organismos geneticamente modificados

A questão que surge desta matéria é saber de que maneira haverá a interferência do DNA da espécie doadora no funcionamento e na estrutura da espécie hospedeira ou receptora e se isso pode acarretar problemas ao equilíbrio ecológico atingido ao longo do tempo pelo ecossistema onde tenham sido liberados os OGMs.

\footnotetext{
4. Faz-se esta ressalva pois o fenótipo é a exteriorização do genótipo, sendo certo que este último se caracteriza pela manifestação do patrimônio genético do indivíduo. Desta fuita, um organismo geneticamente modificado não será, em regra, um híbrido fenotípico pois não apresentará nenhuma característica externa que o diferencie dos demais de sua raça. muito embora seja um híbrido do ponto de vista de seu genótipo. É o que ocorre com a soja geneticamente modificada pois esta, se comparada com um grão de soja "selvagem" ou natural não poderá ser distinguida a menos que se proceda a uma análise de seu DNA. Não se desconhece, todavia, a possibilidade e mesmo a existência de hibridos fenotípicos como é o casu do roedor que desenvolveu uma orelha humana em seu dorso em razão da inclusão, em seu genótipo, de um trecho do DNA humano responsável pela formação da orelha. l' uma rara hipótesu de manifestação fenotípica de uma modificação genética realizada no genoma ou no genútipo.
} 
O meio ambiente foi definido pela Constituição Federal de 1988 como bem de uso comum do povo, determinando que ele permaneça ecologicamente equilibrado. Deve-se salientar que a Constituição brasileira foi a primeira constituição, dentre todas as congêneres, a se preocupar com o meio ambiente e com o equilibrio ecológico, traçando regras claras, precisas e, no mais das vezes, completas a respeito de sua proteção e de seu desenvolvimento.

Uma das medidas previstas pela Constituição Federal é aquele denominado estudo de impacto ambiental (EIA). ${ }^{5}$ Este estudo teria o condão de verificar se determinada obra ou determinada atividade ${ }^{6}$ cognominada de "potencialmente causadora de significativa degradação ao meio ambiente" (CF, art. $225, \S 1^{\circ}$ inciso IV) realmente apresentariam estas potencialidades e mais, se estas potencialidades seriam, ao menos, significativas.?

Percebe-se claramente que o legislador da Constituição, detentor de um poder denominado poder originário (posto que não limitado por qualquer norma que Ihe fora precedente no tempo e na hierarquia) valeu-se de conceitos juridicos indeterminados, ou seja, valeu-se de conceitos não muito precisos e que demandam interpretação de seu conteúdo de acordo com as regras de hermenêutica básicas e válidas para a ciência jurídica.

Com certeza, a hipótese do mencionado inciso constitucional deve ser interpretada segundo a exegese que empresta a esta norma uma certa precaução ${ }^{8}$ do legislador constituinte ao lidar com as possibilidades de dano ao meio ambiente,

5. "O Estudo de Impacto Ambiental (EIA), previsto anteriormente pela legislação. pode ser definido, acompanhando Jain como um estudo das prováveis modificações nas diversas características socioeconômicas e biofisicas do meio ambiente que podem resultar de um projeto proposto."' (Śl.VAA CAPPEI LI. Avaliação de impacto ambiental e o componente da biodiversidade. Revistu Direito Ambiental, São Paulo, v.6, n.24, p.84, out./dez. 2001 -destaques do original).

6. Segundo a Desembargadora Federal Assusete Magalhães. "o plantio da soja roundup ready, no Brasil, insere-se no conceito de atividade e, a rigor, estaria submetido às regras da legislação ambiental." Voto da relatora na apelação cível 2000.01.00.014661-1/DF.

7. Como lembra FȦBio UlhoA Coelho (apud Ângel.a A. M. MACE.do. Produtos transgênicos e o direito a informação do consumidor. Ciência e Direito: Revista Juridica da Fic-Unaes, Campo Grande, v.1, n.2, p.23) o Código de Proteção e Defesa do Consumidor determina que os fornecedores de determinado produto ou serviço estejam certos de terem esgotado todas as possibilidadis contemporâneas de deteç̧ão de eventuais riscos e problemas que possam vir a ser causados aos consumidores - e ao meio - sendo certo que o estudo de impacto ambiental se configura como uma destas possibilidade de detecção mencionadas.

8. Nesse sentido: LEON FREJDA SZKLAROWSKY. Transgênicos : a civilização transgènica e cibernética. Revista de Informaç:ão Legislativa, Brasilia, v. 37, n. 145, p. 51, jan./mar. 2000. 
associados ao cuidado para que não sejam produzidos danos ao equilibrio ecológico.

O problema que surge, então, é o de se saber se os organismos geneticamente modificados possuem, ou não, potencial de lesividade ao meio ambiente no qual venham a ser inseridos e se esta lesividade tem a tendência de ser permanente ou-não.

Segundo as manifestações científicas veiculadas a respeito da engenharia genética, muitas são as dúvidas que ainda assolam a comunidade científica a respeito deste potencial de lesividade. Basta atentar para o fato de que a própria SBPC (Sociedade Brasileira para o Progresso da Ciência) ter su manifestado no sentido de ser duvidosa a condição dos OGMs como agentes agressores do meio ambiente Outros, por seu turno, demonstram enorme convicção de que os transgênicos, quando liberados ao meio ambiente e eventualmente consumidos por outros animais e pelo homem. não causam danos relevantes aos consumidores e que o desequilibrio ecológico causado é normal e decorre da própria intervenção do homem no meio ambiente. ${ }^{9}$

Com efeito, se a própria sociedade interessada no progresso da cientificidade nacional põem-se em posição de cautela, a impressão que passa aos leigos é no sentido de que algo pode mesmo acarretar problemas. In dubio, pro natura. Esta é a máxima que vem agitando os ambientalistas e que tem sido acolhida no seio do Poder Judiciário nacional. Por outro lado, quando ocorreu a utilização de outras técnicas cientificamente consideradas mais perigosas ou tendencialmente mais lesivas, como as induções por mutações nas quais os riscos de que as experiências saíssem do controle, não se recorreu a este princípio jurídico. É bem verdade que à época em que estas experiências começaram a ser lestadas, outra era a filosofia dominante no sistema jurídico nacional e internacional.

A dúvida, então, estaria a exigir do mundo jurídico uma posição de cautela, de precaução.

Esta dúvida que assola parte da comunidade científica diz respeito a uma série de fatores, dentre os quais aqueles destacados pelo Ibama (Instituto Brasileiro do Meio Ambiente e dos Recursos Naturais Renováveis), órgão ligado ao Poder Exccutivo Federal e incumbido da defesa do meio ambiente, em manifestações processuais no processo movido pelo IDEC (Instituto Brasileiro de Defesa do

9. Por todos, ERNESTO PATERNIANI. Uma percepção critica sobre tícnicas de manipulação genética. Revista brasileira de milho e sorgo, v. I n. 1, p. 77-84, 2002. 
Consumidor), e outros, contra a própria União Federal e a Monsanto do Brasil, verbis:

"31. Mencionam-se como riscos: o aparecimento de truços patógenos para os homens, animais e plantas; perturbações para os ecossistemas; transferência de novos traços genéticos para outras espécies, com efeitos indesejáveis; dependência excessiva face às espécies, bem como com ausência de variabilidade genética. (...)"

"32. Além da possibilidade do aparecimento de certos recombinantes inesperados, sintetizando moléculas novas ou exprimindo virus aparentemente inativados, quando se fabrica o organismo geneticamente modificudo, outras riscos surgem ligados à disposição voluntáriu dos OGM (organismos geneticamente modificados). Pode ocorrer a perda de controle dos OGM ou do gene introduzido, ou poderá ser constatado prejuizo para o meio ambiente."

O aparecimento de traços patógenos para os homens, animais e plantas refere-se ao receio de que algumas doenças se manifestem no organismo de outros seres vivos que ingiram ou mantenham alguma espécic de contato com organismos gencticamente modificados. Nisse sentido, as experiências que pretenderam transferir um gene da castanha do Pará para a soja (empresa privada multinacional) ou para o feijão (Embrapa) acarretaram a manifestação de uma série de alergias em pessoas que eram sensíveis a determinada substância milenarmente presente na castanha, e que agora era transferida para aqueles vegetais. Desta forma, os alérgicos que ingeriram o feijão da Embrapa ou a soja da multinacional manifestaram reação patológica. Neste passo, as pretensões das entidades de defesa do consumidor são no sentido de garantir uma rotulagem dos alimentos transgênicos que permitam aos doentes e alérgicos o pleno conhecimento do que estão ingerindo, assumindo, eventualmente, os riscos pelo consumo.

As perturbações para os ecossistemas podem sur sintetizadas e exemplificadas no receio comum de que as variedades transgênicas de certos seres 
vivos desequilibrem o ecossistema ${ }^{10} \mathrm{em}$ razão, por exemplo, de uma mais acelerada velocidade de reprodução, da capacidade de resistirem a certos predadores naturais que acabem morrendo de fome ou mesmo se extinguindo o que pode acarretar, em conseqüência, não-só a proliferação descontrolada do OGM como a extinção de outros seres vivos que se coloquem mais acima na pirâmide alimentar e que serão afetados pelo desaparecimento daquela espécie que se interpõe. normalmente, entre o OGM e si própria.

A transferçncia de novos truços genéticos para outras espécies, com efeitos indesejáveis relaciona-se à possibilidade de que as características enxcrtadas no OGM sejam transmitidas a outras espécies, como pode ocorrer, por exemplo na eventual espécie de cavalos transgênicos, cujas características engenhariadas possam ser repassadas a outras espécies, como os burros que, como já se mencionou, são híbridos do cavalo. Outra possibilidade não descartada por parte dos pesquisadores. mas certamente mais dificil de ser verificada, é que as caracteristicas genéticas possam ser transferidas por meio da cadeia alimentar. Ainda, pode-se referir à possibilidade de que um animal ou vegetal transgênico reproduza-se com a interferência de um congênere não manipulado geneticamente, scm que se possa prever eventuais incompatibilidades genéticas entre ambos ou mesmo problcmas de saúde que possam se manifestar na prole deste cruzamento, uma vez que esta contará com um par de genes dispar, onde o cromossomo doado por um de seus pais conterá uma alteração genética, ao passo que o outro não.

A dependência excessiva face às espécies manifesta-se na possibilidade de que as vantagens econômicas daí advindas suplantem as espécies ditas naturais. tornando absurdamente dispendiosas as culturas e as criações não engenhariadas. que certamente serão deixadas de lado, em detrimento dos OGMs. Por outro lado, como salienta Ernesto Paterniani, as culturas de transgênicos e de outras cultivares que tenham passado por processos e técnicas de melhoramento de suas condições de plantio ou produção são menos dispendiosas pois acabam exigindo uma menor quantidade de produtos agroquímicos. "Este fato, em larga escala considerado, acaba privilegiando o meio ambiente em razão desta menor descarga de produtos ofensivos

10. Os conceitos de poluição e dano ambiental não se confundem. C.f. SilviA CAPPELLI. Avaliação de impacto ambiental e o componente da biodiversidade. Revista Direito Ambiental. São Paulo, v. 6, n. 24. p. 94, out. dez. 2001

11. ERNESTO PATERNIANI. Uma percepção crítica sobre técnicas de manipulação genética. Rerizita brasileira de milho 'sorgo. v. 1 n. 1. p. 80. 
ao ecossistema.

Todavia, o Ibama contra-argumenta afirmando que isso poderia acarretar, em última instância, a ausência de variabilidade genética dentro daquela espécie, na medida em que, mormente entre os vegetais, pode-se programar as plantas para que elas não produzam sementes, o que acarreta não só a dependência do produtor rural em face do detentor da patente daquele produto geneticamente modificado, ${ }^{12}$ uma vez que ele se vê obrigado a adquirir sempre as sementes deste fornecedor, como também gera a dependência do próprio fornecedor, posto que este terá, em última análise, apenas uma certa gama de plantas reprodutoras.

Por fim, o Ibama referiu-se ao aparecimento de certos recombinantes inesperados, sintetizando moléculas novas ou exprimindo vírus aparentemente inativados, quando se fabrica o organismo geneticamente modificado, quando outros riscos surgem ligados à disposição voluntária dos OGM (organismos geneticamente modificados), podendo ocorrer a perda de controle dos OGM ou do gene introduzido, ou a constatação de algum prejuízo para o meio ambiente. Um exemplo refere-se à inserção dos genes do vírus transmissor da AIDS em ratos, experiência realizada nos EUA, em 1980 e que ocasionou a contaminação de TODAS as células somáticas destes camundongos e a verificação de grande variabilidade mutante com 0 conseqüente aumento da carga virulenta desta doença. ${ }^{13}$

São Paulo, março de 2004.

12. A respeito do tema da patentuabilidade de organismos geneticamente modificados e das conseqüências de uma tal patenteabilidade. veja-se: TEODORA ZAMUDIO. Protección juridica de las innovaciones, em especial o Capitulo IV, item 1, p. 62 e seguintes; ELA WIECKO VOLKMER DE CASTILHO. Patentes de produtos de origem biológica. Politica de patentes em saúde humana, p. $70 \mathrm{e}$ seguintes; PA'I RícIa AURŕlia DEL NFro. Biotecnologia. O Brasil e a OMC, p. 79 e seguintes: SABINA NEHMI DE OLIVEIRA. Cultura patentiária e alimentos transgênicos. Revista da ABPI, n. 5I, p. 19-23;

13. Cf. Maria Sulema M DE Budin Pioli. Transgênicos: desafio da era bioindustrial. Meio ambiente, direito e cidadania, p. 91-92. A mesma autora pondera, mais adiantu: "veja o caso do rato infectado, em todas as suas células, com o vírus humano da AIDS. Que escape um só. Vai cruzar com os ratos da natureza, transmitindo aos seus descendentes um vírus com capacidade mutacional nunca antes vista, que é o grande entrave na produção da vacina. O vírus é $100 \%$ mortal aos humanos. Ora, solto, sem controle, ocorrendo mutação genética a cada geração, sempre para sua própria preservação, o virus, como foi dimensionado em pesquisas. poderá atingir formas de disseminação, que hoje não existem" 